DOI https://doi.org/10.30525/978-9934-26-075-9-5

\title{
СПОСІБ ЛІКУВАННЯ НЕСПРОМОЖНОСТІ ШВІВ ДВАНАДЦЯТИПАЛОЇ КИШКИ
}

\author{
Войтів Я. Ю. \\ кандидат медичних наук, дочент, \\ доиент кафедри хірургї та трансплантології \\ Національний університет охорони здоров'я імені П. Л. Шупика \\ м. Київ, Украӥна
}

Незважаючи на розвиток нових хірургічних технологій, неспроможність швів дванадцятипалої кишки (ДПК) з формуванням високої дуоденальної нориці є одним 3 найважчих ускладнень в абдомінальній хірургії. Частота виникнення цього ускладнення, за даними різних авторів, коливається від 0,6 до $18 \%$ [1, с. 5; 2, с. 843].

До цього часу у хірургічній спільноті немає єдиної точки зору на причини розвитку неспроможності швів, алгоритму хірургічної тактики при розвитку цих ускладнень. У сучасних літературних джерелах зустрічаються публікації про ефективне використання EndoVAC терапії при даному ускладненні [3, с. 9; 4, с. 402]. На нашу думку, недоліком вказаних методик $є$ те, що використання EndoVAC системи потребує наявності дороговартісної апаратури для ваккум-терапії, велика кількість дуоденального секрету (жовч, сік підшлункової залози) не завжди може бути аспірована 3 просвіту і вимагає високих показників розрідження тиску. Технічно складним і часто неможливим є проведення зонду для ентерального харчування, який спричиняє зміщення і міграцію губки EndoVAC. Міграція губки через дефект ДПК може спричинити ускладнення з боку інших структур цієї анатомічної ділянки (судини, жовчні шляхи, ПШЗ).

Ми задались метою покращити результатів лікування хворих 3 неспроможністю швів шляхом напрацювання малоінвазивного способу лікування дуоденальної нориці.

Об'єктом ретро- та проспективного дослідження були 14 хворих 3 неспроможністю швів ДПК та дуоденальними норицями, які лікувались у ДУ «НІХТ імені О.О. Шалімова» з 2010 по 2020 рр. Чоловіків було 9, жінок - 5. Вік хворих - від 35 до 68 р., середній вік - 48,2 6,6 р. Пацієнтів дослідної групи (8) лікували за оригінальною напрацьованою методикою, яка передбачає ендоскопічну постановку нітинолового покритого саморозправного стента в ділянку дефекту ДПК та VAC терапія з боку 
зовнішнього отвору нориці (патент України на корисну модель № 143521). Хворих з групи порівняння (6) лікували з використанням класичних операційних втручань 3 лапаротомного доступу (ушивання дефекту ДПК - 3, реконструктивні операції на виключення ДПК - 3, дуоденостомія - 1, дивертикуляризація ДПК - 1). Усім хворим виконували комплексне обстеження, що включало загальноклінічні, спеціальні лабораторні та інструментальні методи дослідження. Зі спеціальних лабораторних досліджень використовували визначення вмісту прокальцитоніну сироватки крові та С-реактивного білку. Статистична обробка результатів досліджень проводилась 3 використанням електронних таблиць Microsoft ${ }^{\circledR}$ Office Excel (2017) та програми для статистичної обробки Statgraphics Professional 16.0.03.

Нами розроблено та запатентовано малоінвазивний ендоскопічний спосіб лікування неспроможності швів дванадцятипалої кишки, який передбачає постановку нітинолового покритого саморозправного стента в ділянку дефекту під ендоскопічним контролем (патент України на корисну модель № 143521).

Спосіб виконують наступним чином: після заведення відеогастроскопу у дистальну частину ДПК, через інструментальний канал ендоскопу за зв'язку Трейца проводять металеву струну-провідник. По струні заводять нітіноловий покритий саморозкривний стент. Проксимальну частину стента розкривають у шлунку, дистальну в дистальних відділах ДПК так, щоб ділянка дефекту знаходилась посередині стенту. Струну-провідник видаляють назовні. Через інструментальний канал за зв'язку Трейца заводять зонд для ентерального харчування. Відеогастроскоп виводять назовні, контролюючи розкриття та розташування стенту в ДПК. Стент видаляють ендоскопічно через 14-21 день. При необхідності, правильність розташування стенту контролюють 3 допомогою рентгеноскопії. До зовнішнього отвору дуоденальної нориці введено спеціальну пористу губку, яку під'єднали до аспіраційної VAC системи з розрідженням 50 мм водного стовпчика. Проведення VAC терапії з боку зовнішнього отвору нориці, яка за рахунок негативного тиску, дозволяє видалити ексудат, кишковий секрет, покращити мікроциркуляцію та зменшити набряк тканин, що скорочує терміни лікування та знижує кількість ускладнень.

У групі порівняння за класичними методиками 3 лапаротомного доступу проліковано 6 пацієнтів. Виконувалось ушивання дефекту ДПК (1), реконструктивні операції на виключення ДПК (3), дуоденостомія (1), дивертикуляризація ДПК (1). Усім пацієнтам проводилось 
дренування черевної порожнини (2-4 дренажі), лапаростома сформована у 2-х випадках.

Середній ліжко-день хворих групи порівняння становив 38,21 44,16 діб, що на 35\% більше ніж у дослідній групі хворих 3 ендоскопічною постановкою стента. Загальна летальність у групі становила 16\%.

Запропонований нами комбінований підхід 3 ендоскопічним встановлення нітинолового покритого саморозправного стента в ділянку дефекту та VAC терапія з боку зовнішнього отвору нориці, сприяє покращенню результатів лікування, а саме скорочення термінів лікування та зниження кількості ускладнень та летальності.

Проведений аналіз клінічно-лабораторних показників свідчить про доцільність, патогенетичну обгрунтованість напрацьованого нами методу хірургічного лікування таких хворих. Середній ліжко-день хворих

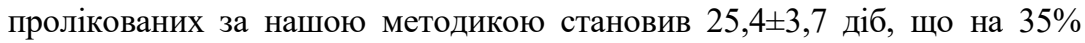
менше ніж у групі хворих оперованих з лапаротомного доступу. Загальна летальність у групі становила 9\%, що майже вдвічі нижче за показники летальності групи порівняння (16\%).

\section{Висновки:}

1. При наявності ускладнення у вигляді дуоденальної нориці нами запропоновано встановлення нітинолового покритого саморозправного стента в ділянку дефекту та VAC терапія з боку зовнішнього отвору нориці, яка за рахунок негативного тиску, дозволяє видалити ексудат, кишковий секрет, покращити мікроциркуляцію та зменшити набряк тканин, що скорочує терміни лікування та знижує кількість ускладнень.

2. Запропонований нами комбінований підхід 3 ендоскопічним встановлення саморозправного стента в ділянку дефекту та VAC терапія 3 боку зовнішнього отвору нориці, сприяє покращенню результатів лікування, а саме скороченню термінів лікування та зниженню кількості ускладнень та летальності.

\section{Література:}

1. Бойко BB, Лєонов AB, Тарабан IA та ін. Неспроможність кишкових анастомозів. Харківська хірургічна школа.2013;6(63):5-8.

2. Sharonne de Z, Usama AA, Rogier AR. Update of complications and functional outcome of the ileo-pouch anal anastomosis: overview of evidence and meta-analysis of 96 observational studies. Int. J. Colorectal Dis. 2012;27:843-853.

3. Мельник ВМ, Пойда ОI. Хірургічна тактика при неспроможності швів міжкишкових анастомозів. Клінічна хірургія. 2016; № 6:8-12. 